\title{
Attitude and its Relationship with Profile Characteristics of the Agricultural Students towards Computer Usage
}

\author{
Priyanka Padashetty $^{1^{*}}$, D.D. Suradkar ${ }^{2}$ and V.B. Kamble ${ }^{3}$ \\ Department of Extension Education, College of Agriculture, Latur Vasantrao Naik \\ Marathwada Krishi Vidyapeeth, Parbhani, India \\ *Corresponding author
}

\section{A B S T R A C T}

\section{Keywords}

Profile, Attitude of respondents, Relationship with attitude, Regression analysis and constraints.

\section{Article Info}

Accepted:

17 October 2017

Available Online:

10 December 2017
Population for the study comprised of students who were undergraduate of Agricultural students in Parbhani and Latur district. From each district one agricultural college was selected for the survey. From each college 60 students ( 30 boys and 30 girls) were selected and the total sample size was one hundred and twenty. This required sample size was selected through purposive random sampling method. One shot case study method of expost-facto medium research design was adopted for this study. Data was coded, tabulated, analyzed and interpreted using suitable statistical parameters. The results showed that most of the students (67\%) were felt comfortable towards computer usage and independent variables like professional education, family type, family occupation, extent of computer use and annual family income had positively significant with attitude of students. Independent variables were interpreted and analyzed with attitude by regression and results showed that professional education, family type, extent of computer usage and health problems had positive and significant effect of respondents towards computer usage. The result showed that respondents were faced some major problems in computer usage that lack of computer and internet facilities, irregular electricity supply and lack of time.

\section{Introduction}

Computer is a device that can be instructed to carry out an arbitrary set of arithmetic or logical operations automatically. Computers are the main technology support as a tool for effective learning and teaching process.

Computer based instruction and computers programs, tools as itself provides much facilities and supports to students' educational life. The computer as productivity tool has great role in education. Computers include hardware and software, word processing functions, graphics, programmed instruction for problem solving, spreadsheets, databases, networking and telecommunications for today high technology developments as a reflective to education. Aytekin et al., (2004) reported that technology is the main support for the students learning developments nowadays.

With shifting from the teacher-centered instruction to child-centered instruction, the role, activities, attitudes, reflections of the students become more important concern to overlook the effectiveness of technology in instruction. 


\section{Materials and Methods}

Population for the study comprised of students who were undergraduate of Agricultural students in Parbhani and Latur district of Marathwada region in Maharashtra state. From each district one agricultural college was selected for the survey. From each college 60 students (30 boys and 30 girls) were selected and the total sample size was one hundred and twenty. This required sample size was selected through purposive random sampling method. One shot case study method of ex-post-facto medium research design was adopted for this study. The scale of 49 items to measure student's attitude towards internet application was developed by Usun (2003) and utilized 20 items by G. R. Angadi (2012) to quantify undergraduate students towards Educational Uses of Internet, but for present study only six suitable items were used.

Attitude of Agriculture students towards computer usage was measured by computing the attitude score. Twenty statements related to computer had ten positive meaning and ten negative meaning were developed in consultation with the experts. For positive meaning statement to a response of strongly agree 5, agree 4, neutral 3, disagree 2 and strongly disagree 1 and scoring procedure was reversed in case of negative meaning statements. Final score was calculated by combining all scores and made as category non-comfortable (upto 65), comfortable (66$77)$ and most comfortable (78 \& above).

\section{Results and Discussion}

\section{Profile characteristics of the agricultural students}

The first objective of the study was to describe profile characteristics of undergraduate students. Majority 61 per cent of the respondents belongs to nuclear family. 57.50 per cent of the students are medium sized family. As with regard to children future, most of the parents have desired to lead independent life to provide proper accommodation, good education and various facilities they were selected nuclear family and to provide advanced technologies like computer, laptop, to get bright future to their kids. 49.16 per cent of the students had taken MS-CIT computer course. This might be due to respondents had basic knowledge of computer. Similar results were also observed by Abubakar and Adetimirin (2015).38.00 per cent of the respondents had family education above degree.56.67 per cent of the parents were semi professionists like school teacher, businessmen, agriculturists, clerk, and accountant. This may be due to the giving importance to education, villager send their children for higher education and if family background is better, then children will get proper education and to occupy better future for their life they go for higher education (Table 1).

40.00 per cent of the respondents were daily users, 49.17 per cent of the respondents were regularly internet browsers with 72.5 per cent of the respondents were spent time above two hours. Now a day computer, laptops are very much necessary for daily routine works. Students were worked by using computer for different activities like searching study material, making presentation, playing games etc. They had more attachment with social media like Gmail, face book, you tube, whatsapp, twitter, Instagram. 32.5 per cent of the respondents were never faced any health problems in using internet because the youngers face more health problems than elders and even by using computer or laptop they relieve tension, depression and nervousness and 65.83 per cent of the students' family had high level of annual income. As majority of the family were semi 
professionists, their income is also good. Similar results were also observed by Jayalaxmi Pawar and Uma (2009, 2011).

\section{Attitude of the agricultural students towards computer usage}

The results showed that ten positive statements towards computer usage. In that most of the students $(93.33 \%)$ were strongly agreed to knowledge of computer and Internet is essential for students and no one had disagreed to it. (75\%), (15\%) and (10\%) of the students were strongly agreed, agreed and neutral respectively to access the computer more at college than home. $(72.5 \%)$ of the students were strongly agreed that internet is easier to use than library. (69.17\%) and $(23.33 \%)$ of the students were strongly agreed and agreed respectively for computer is used as learning fun. (66.67\%) of the students strongly agreed that computer is most important as research tools. $(67.5 \%)$ of the students were believed that the Internet to be as informative as teachers. 65\% (strongly agreed), $28.33 \%$ (agreed) and $6.67 \%$ (neutral) of the respondents were felt comfortable in using computer. $53.34 \%$ (strongly agreed), $19.16 \%$ (agreed), $16.66 \%$ (neutral) but few $10.82 \%$ (disagreed) of the students were accepted that computer has involved in their life at all fields (Table 2).

Respondents were responded to negative statements also. 51\% (strongly disagreed), $25 \%$ (agreed) of the students were reacted that computer is not difficult to use and (20\%) neutral and (3.33\%) agreed to it. $91.66 \%$ of the respondents were strongly disagreed to useless information in internet. 50\%, 43.33\% and $6.67 \%$ of the respondents were strongly disagreed, disagreed and neutral respectively felt aggressive and hostile towards computer usage. $74.16 \%$ of the students love to use the computers. $67.5 \%$ (strongly disagreed), $32.5 \%$ (disagreed) of the students were not made them angry by using computers.
$33.34 \%$ of the students were neutral in accepting that they are not good users of computers, $5 \%$ of the students were strongly agreed to it. $40 \%$ (strongly disagreed), $43.34 \%$ (disagreed) and $16.67 \%$ (neutral) of the students accepted that using computer, browsing confuses their mind. No one students were agreed for wasting time in learning computers (Fig. 1).

Majority 67.00 per cent of the respondents were felt comfortable for using computer, 18.00 per cent of the respondents were felt most comfort and only 15.00 per cent of the respondents were felt non-comfortable for using computer (Table 3). Majority of the respondents had positive, favourable attitude and comfort in using computer. The findings are in line with Opoku et al., (2014), Rhema and Miliszewska (2014) and Ahmadpour et al., (2016).

\section{Relationship between profiles of respondents with attitude towards computer usage}

The results revealed that out of eight independent variables, four variables had exhibited positive significant relationship with attitude of the respondents. Professional education, family type, family occupation, annual family income and extent of computer usage had positive significant at 5 per cent and 1 per cent level respectively. Remaining variables like family size, family education and health problems were non-significant.

\section{Regression analysis}

Multiple regression analysis of independent variables with the attitude. The table 4 indicates that, $\mathrm{R}$ value 0.4102 indicated that all the selected independent variables put together explained about 41.02 per cent variation in the attitude was explained by eight independent variables. 
Table.1 Profile characteristics of agricultural student $(\mathrm{N}=120)$

\begin{tabular}{|c|c|c|c|}
\hline Profile characters & Category & Frequency & Percentage \\
\hline \multirow[t]{4}{*}{ Professional education } & MS-CIT & 59 & 49.16 \\
\hline & DOEACC & 1 & 0.83 \\
\hline & $\mathrm{CCC}, \mathrm{C}++$ & 34 & 28.33 \\
\hline & No course taken & 33 & 27.50 \\
\hline \multirow[t]{2}{*}{ Family type } & Nuclear & 73 & 61.00 \\
\hline & Joint & 47 & 39.00 \\
\hline \multirow[t]{3}{*}{ Family size } & Small & 24 & 20.00 \\
\hline & Medium & 69 & 57.50 \\
\hline & Large & 27 & 22.50 \\
\hline \multirow[t]{5}{*}{ Family education } & Illiterate & 05 & 04.00 \\
\hline & Primary school & 16 & 13.00 \\
\hline & High school & 30 & 25.00 \\
\hline & Pre-university/diploma & 24 & 20.00 \\
\hline & Degree and above & 45 & 38.00 \\
\hline \multirow[t]{4}{*}{ Family occupation } & Non-worker / unemployed & 11 & 9.16 \\
\hline & Skilled worker-tailor, carpenter, potter etc & 14 & 11.64 \\
\hline & $\begin{array}{l}\text { Semi professionists- school teacher, } \\
\text { businessmen, agriculturist, clerk, } \\
\text { accountant, librarian, assistant. }\end{array}$ & 68 & 56.67 \\
\hline & $\begin{array}{l}\text { Higher professionists- engineer, doctor, } \\
\text { professor, manager, law administrator. }\end{array}$ & 27 & 22.50 \\
\hline \multirow[t]{4}{*}{ Extent of computer use } & Daily & 48 & 40 \\
\hline & Fortnightly & 30 & 25 \\
\hline & Monthly & 24 & 20 \\
\hline & Rarely & 18 & 15 \\
\hline \multirow{3}{*}{ I. Frequency of usage } & Regularly & 59 & 49.17 \\
\hline & Occasionally & 49 & 40.83 \\
\hline & Never & 12 & 10.00 \\
\hline \multirow[t]{2}{*}{ ii. Time spent } & Minimum(1 hr) & 33 & 27.5 \\
\hline & Maximum ( $2 \mathrm{hr}$ and above $)$ & 87 & 72.5 \\
\hline \multirow[t]{4}{*}{ Health problems } & Eye related- eye strain, burning or irritation & 37 & 30.83 \\
\hline & Muscle related- backache, body pain & 18 & 15 \\
\hline & Headache & 26 & 21.67 \\
\hline & Never faced any problem & 39 & 32.50 \\
\hline \multirow[t]{3}{*}{ Annual family income } & Normal & 21 & 17.51 \\
\hline & High & 79 & 65.83 \\
\hline & Very high & 20 & 16.66 \\
\hline
\end{tabular}


Table.2 Distribution of the respondents according to their attitude towards computer usage

\begin{tabular}{|c|c|c|c|c|c|c|}
\hline $\begin{array}{l}\text { SI. } \\
\text { NO. }\end{array}$ & Statement & $\begin{array}{l}\text { Strongly } \\
\text { agree }\end{array}$ & Agree & Neutral & Disagree & $\begin{array}{l}\text { Strongly } \\
\text { disagree }\end{array}$ \\
\hline 1. & $\begin{array}{l}\text { I would feel comfortable in } \\
\text { using computer }\end{array}$ & $\begin{array}{l}78 \\
(65 \%)\end{array}$ & $\begin{array}{l}34 \\
(28.33 \%)\end{array}$ & \begin{tabular}{|l|}
8 \\
$(6.67 \%)$
\end{tabular} & - & - \\
\hline 2. & $\begin{array}{l}\text { I find the Internet to be as } \\
\text { informative as teachers }\end{array}$ & $\begin{array}{l}81 \\
(67.5 \%)\end{array}$ & $\begin{array}{l}27 \\
(22.5 \%)\end{array}$ & $\begin{array}{l}12 \\
(10 \%)\end{array}$ & - & - \\
\hline 3. & $\begin{array}{l}\text { I enjoy getting information } \\
\text { more from written material than } \\
\text { Internet }\end{array}$ & $\begin{array}{l}71 \\
(59.16 \%)\end{array}$ & $\begin{array}{l}36 \\
(30 \%)\end{array}$ & $\begin{array}{l}13 \\
(10.84 \%)\end{array}$ & - & - \\
\hline 4. & $\begin{array}{l}\text { I like to read books for getting } \\
\text { information about computers. }\end{array}$ & $\begin{array}{l}49 \\
(40.83 \%)\end{array}$ & $\begin{array}{l}31 \\
(25.84 \%)\end{array}$ & $\begin{array}{l}37 \\
(30.83 \%) \\
\end{array}$ & $\begin{array}{l}3 \\
(2.5 \%)\end{array}$ & - \\
\hline 5. & I use computer as learning fun & $\begin{array}{l}83 \\
(69.17 \%)\end{array}$ & $\begin{array}{l}28 \\
(23.33 \%)\end{array}$ & \begin{tabular}{|l|}
9 \\
$(7.5 \%)$ \\
\end{tabular} & - & - \\
\hline 6. & $\begin{array}{l}\text { I involve computers to my life } \\
\text { at all fields }\end{array}$ & $\begin{array}{l}64 \\
(53.34 \%)\end{array}$ & $\begin{array}{l}23 \\
(19.16 \%)\end{array}$ & $\begin{array}{l}20 \\
(16.66 \%)\end{array}$ & $\begin{array}{l}13 \\
(10.82 \%)\end{array}$ & - \\
\hline 7. & $\begin{array}{l}\text { I access the computer more at } \\
\text { college than at home }\end{array}$ & $\begin{array}{l}90 \\
(75 \%)\end{array}$ & $\begin{array}{l}18 \\
(15 \%)\end{array}$ & $\begin{array}{l}12 \\
(10 \%)\end{array}$ & - & - \\
\hline 8. & $\begin{array}{l}\text { Computer is Important like } \\
\text { other research tools }\end{array}$ & $\begin{array}{l}80 \\
(66.67 \%)\end{array}$ & $\begin{array}{l}11 \\
(9.18 \%)\end{array}$ & $\begin{array}{l}29 \\
(24.15 \%) \\
\end{array}$ & - & - \\
\hline 9. & $\begin{array}{l}\text { Internet is easier to use than } \\
\text { library }\end{array}$ & $\begin{array}{l}87 \\
(72.5 \%)\end{array}$ & $\begin{array}{l}19 \\
(15.83 \%)\end{array}$ & $\begin{array}{l}14 \\
(11.67 \%)\end{array}$ & - & - \\
\hline 10 & $\begin{array}{l}\text { Knowledge of computer and } \\
\text { Internet is essential for students }\end{array}$ & $\begin{array}{l}112 \\
(93.33 \%)\end{array}$ & $\begin{array}{l}8 \\
(6.67 \%)\end{array}$ & - & - & - \\
\hline 11. & Computer is difficult to use & - & $\begin{array}{l}4 \\
(3.33 \%)\end{array}$ & $\begin{array}{l}24 \\
(20 \%)\end{array}$ & $\begin{array}{l}30 \\
(25 \%)\end{array}$ & $\begin{array}{l}62 \\
(51.66 \%)\end{array}$ \\
\hline 12. & $\begin{array}{l}\text { Internet contains useless } \\
\text { information }\end{array}$ & - & - & - & $\begin{array}{l}10 \\
(8.34 \%) \\
\end{array}$ & $\begin{array}{l}110 \\
(91.66 \%)\end{array}$ \\
\hline 13. & $\begin{array}{l}\text { I feel aggressive and hostile } \\
\text { towards computer. }\end{array}$ & - & - & $\begin{array}{l}8 \\
(6.67 \%) \\
\end{array}$ & $\begin{array}{l}52 \\
(43.33 \%) \\
\end{array}$ & $\begin{array}{l}60 \\
(50 \%)\end{array}$ \\
\hline 14 & $\begin{array}{l}\text { It is not interesting to solve } \\
\text { problems with computers. }\end{array}$ & $\begin{array}{l}26 \\
(21.66 \%) \\
\end{array}$ & $\begin{array}{l}13 \\
(10.84 \%) \\
\end{array}$ & $\begin{array}{l}38 \\
(31.67 \%) \\
\end{array}$ & $\begin{array}{l}24 \\
(20 \%) \\
\end{array}$ & $\begin{array}{l}19 \\
(15.83 \%)\end{array}$ \\
\hline 15 & $\begin{array}{l}\text { Learning computers is only } \\
\text { losing time for me. }\end{array}$ & - & - & - & $\begin{array}{l}37 \\
(28.33 \%) \\
\end{array}$ & $\begin{array}{l}83 \\
(69.17 \%)\end{array}$ \\
\hline 16 & I hate from computers. & - & - & - & $\begin{array}{l}43 \\
(35.84 \%) \\
\end{array}$ & $\begin{array}{l}89 \\
(74.16 \%) \\
\end{array}$ \\
\hline 17 & $\begin{array}{l}\text { Engaging with computers make } \\
\text { me angry }\end{array}$ & - & - & - & $\begin{array}{l}39 \\
(32.5 \%) \\
\end{array}$ & $\begin{array}{l}81 \\
(67.5 \%)\end{array}$ \\
\hline 18 & $\begin{array}{l}\text { Using computer and Accessing, } \\
\text { surfing and browsing the } \\
\text { Internet confuses my mind. }\end{array}$ & - & - & $\begin{array}{l}20 \\
(16.67 \%)\end{array}$ & $\begin{array}{l}52 \\
(43.33 \%)\end{array}$ & $\begin{array}{l}48 \\
(40 \%)\end{array}$ \\
\hline 19 & $\begin{array}{l}\text { I get sinking feeling when I } \\
\text { think of trying to use Internet }\end{array}$ & - & $\begin{array}{l}8 \\
(6.67 \%)\end{array}$ & \begin{tabular}{|l|}
84 \\
$(70 \%)$ \\
\end{tabular} & $\begin{array}{l}16 \\
(13.33 \%) \\
\end{array}$ & $\begin{array}{l}12 \\
(10 \%) \\
\end{array}$ \\
\hline 20 & $\begin{array}{l}\text { I believe that I will not be good } \\
\text { user at computer }\end{array}$ & $\begin{array}{l}6 \\
(5 \%)\end{array}$ & $\begin{array}{l}17 \\
(14.16 \%)\end{array}$ & $\begin{array}{l}40 \\
(33.34 \%)\end{array}$ & $\begin{array}{l}34 \\
(28.35 \%)\end{array}$ & $\begin{array}{l}23 \\
(19.15 \%)\end{array}$ \\
\hline
\end{tabular}


Table.3 Distribution of the respondents according to overall attitude of respondents towards of computer usage

\begin{tabular}{|l|l|l|}
\hline Category & Frequency & Percentage \\
\hline Non-comfortable & 18 & 15 \\
\hline Comfortable & 80 & 67 \\
\hline Most comfortable & 22 & 18 \\
\hline
\end{tabular}

Table.4 Relationship between profile of respondents with attitude towards computer usage

\begin{tabular}{|l|l|l|}
\hline Sl. No. & Profile characteristics & Attitude \\
\hline 1 & Professional education & $0.2078^{*}$ \\
\hline 2 & Family type & $0.2258^{*}$ \\
\hline 3 & Family size & $0.1176 \mathrm{NS}$ \\
\hline 4 & Family education & $0.1219 \mathrm{NS}$ \\
\hline 5 & Family occupation & $0.2012^{*} \mathrm{~S}$ \\
\hline 6 & Extent of computer usage & $0.4776^{* *}$ \\
\hline 7 & $\begin{array}{l}\text { Health problems related to computer } \\
\text { usage }\end{array}$ & $0.1421 \mathrm{NS}$ \\
\hline 8 & Annual family income & $0.1992^{*}$ \\
\hline
\end{tabular}

$* \& * *$ correlation is significant at the 0.05 and 0.01 level respectively.

NS- Non-significant.

Table.5 Multiple regression analysis of independent variables with the attitude

\begin{tabular}{|l|l|l|c|l|}
\hline $\begin{array}{l}\text { Sl. } \\
\text { No. }\end{array}$ & Independent variable & $\begin{array}{l}\text { Regression } \\
\text { coefficient }\end{array}$ & $\begin{array}{l}\text { Standard } \\
\text { error }\end{array}$ & $\begin{array}{l}\text { “t” } \\
\text { value }\end{array}$ \\
\hline 1 & Professional education & 1.0697 & 0.4596 & $2.3274^{*}$ \\
\hline 2 & Family type & 4.0581 & 1.5885 & $2.5546^{*}$ \\
\hline 3 & Family size & -0.2036 & 0.2856 & -0.7128 \\
\hline 4 & Family education & 0.3095 & 0.6006 & 0.6501 \\
\hline 5 & Family occupation & -0.1390 & 0.9532 & -0.1458 \\
\hline 6 & Extent of computer usage & 1.3413 & 1.6641 & $2.2911^{*}$ \\
\hline 7 & Health problems & 0.9518 & 0.4730 & $2.0121^{*}$ \\
\hline 8 & Annual family income & 0.2872 & 0.3686 & 0.7793 \\
\hline
\end{tabular}

$\mathrm{R}^{2}=41.02, \mathrm{~F}$ value $=09.241$

$*=$ Significant at 0.05 level of probability

$* *=$ Significant at 0.01 level of probability 
Table.6 Distribution of the respondents according to constraints faced in computer use

\begin{tabular}{|r|l|l|l|l|l|}
\hline Sl. & \multirow{2}{*}{ Constraints } & \multicolumn{3}{l|}{ Yes } & \multicolumn{2}{l|}{ No } \\
\cline { 3 - 6 } & & Freq & \% & Freq & \% \\
\hline 1 & High cost of internet access & 120 & 100.00 & 0 & 0 \\
\hline 2 & Lack of computer \& internet facilities & 116 & 96.66 & 4 & 3.33 \\
\hline 3 & Irregular electricity supply & 109 & 90.83 & 11 & 9.16 \\
\hline 4 & Lack of time & 105 & 87.5 & 15 & 12.5 \\
\hline 5 & $\begin{array}{l}\text { No proper working of computer \& no } \\
\text { MS office, PDF converter. }\end{array}$ & 44 & 36.66 & 70 & 58.33 \\
\hline 6 & Lack of computer literacy & 28 & 23.30 & 92 & 76.70 \\
\hline 7 & Lack of training on how to use computer & 16 & 13.00 & 104 & 87.00 \\
\hline 8 & Lack of interest & 12 & 10.00 & 108 & 90.00 \\
\hline
\end{tabular}

Fig.1 Distribution of respondents according to overall students' attitude towards computer usage

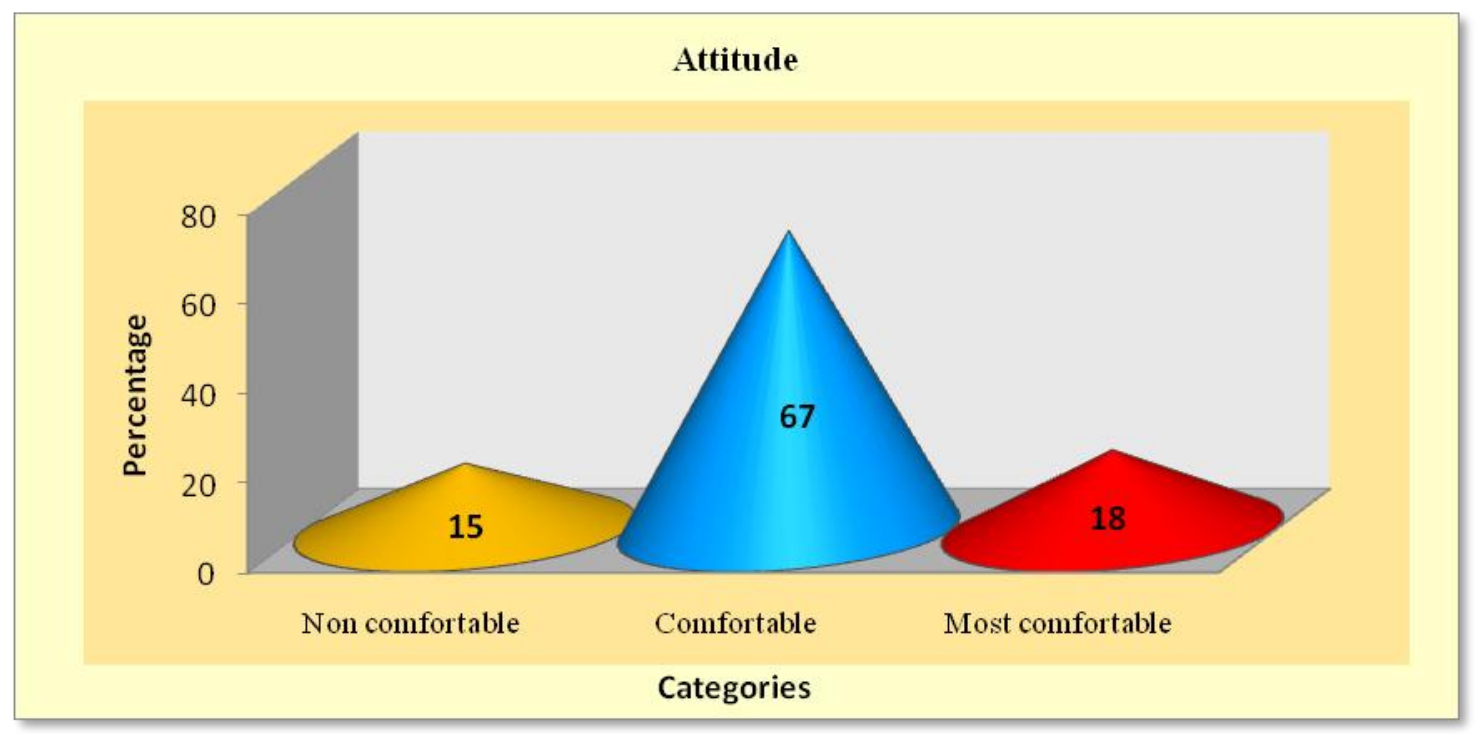

It was also observed that out of eight independent variables professional education, family type, extent of computer usage and health problems had positive and significant effect on attitude of respondents towards computer usage.

\section{Constraints faced by the agricultural students in computer usage}

The data mentioned in the Table 5 showed that 76.7 per cent of the students had computer literacy while 23.30 per cent of the students were lack in computer literacy. 87 per cent of the students had training or courses of computer while only 13 per cent of the students were lack in training or courses. All the students $(100 \%)$ were felt that there was a lack of time. 90 per cent of the students had interest while only 10 per cent of the students had no interest in computer usage.109 per cent of the students had faced problem of irregular electric supply while only 9.16 per cent of the students were not faced. 96.66 per cent of the students were lacking of computer and internet facilities and 36.66 per cent of the students were faced that most of the computers were not working 
properly and not having basic applications like MS word, Excel and PDF converter (Table 6).

It was concluded that significant use of computer is not taking by the agricultural students though most of them had taken MSCIT course. Even in the college more importance was given to other courses than computer course and very least use of it. Most of the students were preferred to have nuclear families and they showed positive attitude towards nuclear and small or medium sized family.

While discussing with students came to know that if father occupation and their education, family income has to be better for fulfilling their children's requirements then it shows significant and positive attitude towards computer usage. As compared to other fields like engineer, medical students etc. the agricultural students had less in extent of using computer. So, majority of the students were not faced any health problems but some students faced getting headache, eye strain. We recommend the University of Parbhani and its sub campus that continue to invest in academic computer services and open access computer labs and installed basic software applications like MS office and PDF converter. As being an Agriculture student, they should know how to search engines, journals, study material, different technologies used by progressive farmers through computer services. So, computer knowledge is very necessary for the students and should add computer course syllabus for their curriculum.

\section{Acknowledgement}

The work was supported by department of Extension Education, College of Agriculture Latur, Vasanth Rao Naik Mrathwad Krishi Vidyapeeth, Parbhani (MH), India. We are thankful to Dr. D. D. Suradkar and Dr. V. B. Kamble for their assistance in the completion of this research work.

\section{References}

Abubakar and Adetimirin. 2015. Influence of computer literacy on postgraduates' use of e-resources in Nigerian university libraries. Library Philosophy and Practice (e-j.) Libraries at University of Nebraska-Lincoln Spring 6-18-2015: 1207.

Ahmadpour, A, Mirdamadi. S.M, and Soltani, S., 2016. Attitude towards On-the-job E-learning: The Case of Agricultural Extension Workers in Iran. J. Agr. Sci. Tech. (2016) 18: 27-38.

Angadi, G.R., 2012, Post Graduate Students Attitude towards the use of Internet. International Journal of Education and Psychological Research (IJEPR) 1: 3037.

Aytekin, Mehmet, Fahme, Zehra and Fahriye 2004. Attitudes of Students toward Computers. The Turkish Online Journal of Educational Technology - TOJET January 2004. 3 Issue 1 Article

Dery Samuel, V., Godi., S.A., and D.D., 2016. Knowledge and use of information and communication technology by health sciences students of the University of Ghana. Ghana Med $J$ 2016; 50(2): 180-188.

Emily B.R., Irani, T. and Brian E.M. 2008. Internet as an information source: attitudes and usage of students enrolled in a college of agriculture course. $J$. Agri. Edu. 49(2):121-132

Jayalaxmi Powar, B.C and Uma, S.H. 2009. Opinion and knowledge of children and adolescents towards computer usage, Karnataka J.Agri.Sci., 24(4):3-516-519.

Jayalaxmi Powar, B.C. and Uma. S.H. 2011. Effects of computer on social life of children and adolescents. Karnataka 
J.Agric.Sci.Dharwad. 3: 375-377.

Mamoni Das, N. N. Puzari and B.K. Ray 2010. Impact of training of skill and knowledge development of rural women. Agri. Extn. Rev., Pp. 29-31.

Opoku, Mustapha, Osman, Kuranchie and Alfred 2014, Understanding student attitude towards computer education: A Survey of SHS in the Sunyani Municipality. Academic Journal of
Interdisciplinary Studies, 3(1): 22814612.

Rhema and Miliszewska, 2014. Socioeconomic characteristics of rural family issues in informing science and information technology, 11: 169-190.

Usun S. 2003. Undergraduate students attitude towards educational uses of internet, interactive educational multimedia, 7:46-62

\section{How to cite this article:}

Priyanka Padashetty, D.D. Suradkar and Kamble, V.B. 2017. Attitude and its Relationship with Profile Characteristics of the Agricultural Students towards Computer Usage. Int.J.Curr.Microbiol.App.Sci. 6(12): 2423-2431. doi: https://doi.org/10.20546/ijcmas.2017.612.280 